\title{
AARC Clinical Practice Guideline: Blood Gas Analysis and Hemoximetry: 2013
}

\author{
Michael D Davis RRT, Brian K Walsh RRT-NPS RPFT FAARC, \\ Steve E Sittig RRT-NPS FAARC, and Ruben D Restrepo MD RRT FAARC
}

\begin{abstract}
We searched MEDLINE, CINAHL, and Cochrane Library database for articles published between January 1990 and December 2012. The update of this clinical practice guideline is based on 237 clinical trials, 54 reviews, and 23 meta-analyses on blood gas analysis (BGA) and hemoximetry. The following recommendations are made following the Grading of Recommendations Assessment, Development, and Evaluation scoring system. BGA and hemoximetry are recommended for evaluating a patient's ventilatory, acid-base, and/or oxygenation status. BGA and hemoximetry are suggested for evaluating a patient's response to therapeutic interventions. BGA and hemoximetry are recommended for monitoring severity and progression of documented cardiopulmonary disease processes. Hemoximetry is recommended to determine the impact of dyshemoglobins on oxygenation. Capillary BGA is not recommended to determine oxygenation status. Central venous BGA and hemoximetry are suggested to determine oxygen consumption in the setting of early goaldirected therapies. For the assessment of oxygenation, a peripheral venous $\mathbf{P}_{\mathrm{O}_{2}}$ is not recommended as a substitute for an arterial blood measurement $\left(\mathbf{P}_{\mathrm{aO}_{2}}\right)$. It is not recommended to use venous $\mathbf{P}_{\mathrm{CO}_{2}}$ and $\mathbf{p H}$ as a substitute for arterial blood measurement of $\mathbf{P}_{\mathrm{acO}}$ and $\mathbf{p H}$. It is suggested that hemoximetry is used in the detection and evaluation of shunts during diagnostic cardiac catheterization. Key words: blood gases; blood gas analysis; hemoximetry; guidelines. [Respir Care 2013; 58(10):1694-1703. (C) 2013 Daedalus Enterprises]
\end{abstract}

\section{BGA 1.0 DESCRIPTION}

Analysis of arterial and mixed venous blood provides information concerning the oxygenation, ventilatory, and acid-base status of the patient from whom the specimen was obtained. Analysis of samples from other sources (ie, capillary, peripheral venous, umbilical venous samples, and

\footnotetext{
Mr Davis is affiliated with the Adult Health and Nursing System, Virginia Commonwealth University, Richmond, Virginia. Mr Walsh is affiliated with Boston Children's Hospital, Boston, Massachusetts. Mr Sittig is affiliated with the Mayo Clinic, Rochester, Minnesota. Dr Restrepo is affiliated with the University of Texas Health Science Center at San Antonio, San Antonio, Texas.
}

The authors have disclosed no conflicts of interest.

Correspondence: Michael D Davis RRT, Department of Adult Health Nursing Systems, Medical College of Virginia, School of Nursing Building, Virginia Commonwealth University, Room 4010c, 1100 East Leigh Street, Richmond VA 23298-0567. E-mail: mdavis35@vcu.edu.

DOI: $10.4187 /$ respcare. 02786
$\mathrm{pH}$ measured from other body fluids) may provide limited information. The variables most generally measured are the $\mathrm{P}_{\mathrm{aCO}}, \mathrm{P}_{\mathrm{aO}}$, and $\mathrm{pH}$. Additional clinically useful variables are the concentration of total hemoglobin, oxyhemoglobin saturation, saturations of the dyshemoglobins (carboxyhemoglobin and methemoglobin), ${ }^{1-7}$ and other calculated or derived values, such as plasma bicarbonate and base excess/deficit.

While there is some evidence that venous and arterial $\mathrm{pH}, \mathrm{P}_{\mathrm{CO}_{2}}$, and $\mathrm{HCO}_{3}$ may have sufficient agreement as to be clinically comparable in a variety of clinical settings, the venous blood gas (VBG) obtained from a central line should be considered a surrogate for arterial blood gas (ABG) only in very specific clinical circumstances. ${ }^{8-12}$

Central venous oxygen saturation and mixed venous oxygen saturation can reflect the relationship between oxygen delivery and consumption. Venous oximetry monitoring may reduce the morbidity and mortality of patients undergoing major surgery, or patients with septic shock, as it allows implementation of early goal-directed therapies. $^{12-14}$ 
This is an update of a previously published AARC clinical practice guideline from $2001 .{ }^{15}$ The recommendations provided in this clinical practice guideline are based on a search of the MEDLINE, CINAHL, and Cochrane Library databases for articles published between January 1990 and December 2012. The update of this clinical practice guideline is based on 237 clinical trials, 54 reviews, and 23 meta-analyses on blood gas analysis (BGA) and hemoximetry.

\section{BGA 2.0 SETTING}

Blood gas analysis should be performed by trained individuals, ${ }^{16,17}$ in a variety of settings, including, but not limited to:

2.1 hospital laboratory

2.2 hospital emergency department

2.3 patient-care area

2.4 clinic laboratory

2.5 laboratory in physician's office ${ }^{16}$

2.6 inter-facility critical care transport ${ }^{18,19}$

2.7 pulmonary diagnostic laboratory

2.8 operating room suite

2.9 cardiac catheterization laboratory ${ }^{20}$

2.10 postmortem examination ${ }^{21}$

\section{BGA 3.0 INDICATIONS}

3.1 Indications for BGA and hemoximetry include: 3.1.1 the need to further evaluate the adequacy of a patient's ventilatory $\left(\mathrm{P}_{\mathrm{aCO}_{2}}\right)$, acid-base $(\mathrm{pH})$, and oxygenation $\left(\mathrm{P}_{\mathrm{aO}_{2}}\right.$ and oxyhemoglobin saturation) status, the oxygen-carrying capacity $\left(\mathrm{P}_{\mathrm{aO}}\right.$, oxyhemoglobin saturation, total hemoglobin, and dyshemoglobin saturations) $)^{1,6,7}$ and intrapulmonary shunt

3.1.2 the need to quantify the response to therapeutic intervention (eg, supplemental oxygen administration, mechanical ventilation) or diagnostic evaluations (eg, exercise desaturation) $)^{4,6,7,22}$

3.1.3 the need to assess early goal-directed therapy measuring central venous oxygen saturation in patients with sepsis, septic shock and after major surgery 23

3.1.4 the need to monitor severity and progression of documented disease processes ${ }^{4,7}$

3.1.5 the need to assess inadequacy of circulatory response

3.1.5.1 A high central venous/arterial $\mathrm{P}_{\mathrm{CO}_{2}}$ difference can indicate inadequate perfusion, as observed in severe hemorrhagic shock, poor cardiac output, during cardiopulmonary resuscitation, and after cardiopulmonary bypass. ${ }^{24-28}$
3.1.6 the need to assess acid-base status when an arterial blood gas cannot be obtained. A central venous sample or capillary sample is preferable to a peripheral venous sample. A peripheral venous sample reflects only local tissue consumption versus delivery.

3.1.6.1 When analyzed by an accurate instrument and in very specific clinical conditions, an adjusted central $\mathrm{VBG}^{12}$ or $\mathrm{CBG}^{29}$ may show sufficient agreement with some parameters of the ABG. ${ }^{10}$

3.1.6.2 VBG and CBG analysis has been found to reliably predict the $\mathrm{ABG}$ values of $\mathrm{pH}, \mathrm{P}_{\mathrm{CO}_{2}}$, and $\mathrm{HCO}_{3}$ in patients with exacerbation of COPD. ${ }^{8,9,11,29}$

3.1.6.3 A peripheral venous blood sample can be used to evaluate the acid-base status in patients with uremia and diabetic ketoacidosis. ${ }^{30,31}$

\section{BGA 4.0 CONTRAINDICATIONS}

Contraindications to performing $\mathrm{pH}$-blood gas analysis and hemoximetry include:

4.1 an improperly functioning blood gas analyzer

4.2 a blood gas analyzer that has not had functional status validated through

4.2.1 analysis of commercially prepared quality control products or tonometered whole blood or

4.2.2 participation in a proficiency testing pro$\operatorname{gram}(\mathrm{s})^{3,32-38}$

4.3 a specimen that has not been properly anticoagulated $1,3,36,39,40$

4.4 a specimen containing visible air bubbles ${ }^{1,7}$

4.5 a specimen that has been stored at room temperature for longer than $30 \mathrm{~min}$ in a plastic vessel, stored at room temperature for longer than $5 \mathrm{~min}$ for a shunt study, or stored at room temperature in the presence of an elevated leukocyte or platelet count. In the case of samples that must be kept for longer than $30 \mathrm{~min}$, they should be drawn and stored in a glass vessel and chilled to $0-4^{\circ} \mathrm{C}$. Since $\mathrm{P}_{\mathrm{aO}_{2}}$ in samples drawn from subjects with very high leukocyte counts can decrease rapidly, immediate cooling and analysis are necessary in this patient population. , $^{1,39,41-52}$

4.6 an incomplete requisition that precludes adequate interpretation and documentation of results and for which attempts to obtain additional information have been unsuccessful. Requisitions should contain

4.6.1 patient's name and at least one other unique identifier, such as medical record number, birth date or age, or date and time of sampling 53

4.6.2 location of patient 
4.6.3 name of requesting physician or authorized independent licensed practitioner

4.6.4 clinical indication and tests to be performed 4.6.5 sample source (arterial line, central venous catheter, peripheral artery)

4.6.6 breathing frequency and (for the patient on supplemental oxygen) $\mathrm{F}_{\mathrm{IO}_{2}}$ or oxygen flow

4.6.7 site from which sample was acquired (eg, radial artery, femoral artery, vein) ${ }^{54}$

4.6.8 ventilator settings for the mechanically or noninvasively ventilated patient (tidal volume, breathing frequency, $\mathrm{F}_{\mathrm{IO}_{2}}$, mode)

4.6.9 signature or initials of the person who obtained the sample. ${ }^{1,16}$ It may also be useful to note body temperature, 55 activity level and time, and working diagnosis. The test requisition should be electronically generated or handwritten, and must be signed by the person ordering the test. Oral requests must be supported by written authorization within 30 days (unless local regulations specify a different timeframe). ${ }^{3,16}$

4.7 an inadequately labeled specimen, lacking the patient's full name and other unique identifier (eg, medical record number), or date and time of sampling 1,3

\section{BGA 5.0 HAZARDS/COMPLICATIONS}

Possible hazards or complications include:

5.1 infection of specimen handler from blood carrying the human immunodeficiency virus, hepatitis $\mathrm{C}$, other blood-borne pathogens ${ }^{3,17,56-58}$

5.2 inappropriate patient medical treatments based on improperly analyzed blood specimen or from analysis of an unacceptable specimen or from incorrect reporting of results

5.3 in the case of samples received from a contaminated (isolation) room, cross-contamination of areas of the hospital or handlers of the sample

5.4 improperly identified patient

\section{BGA 6.0 LIMITATIONS OF PROCEDURE/ VALIDATION OF RESULTS}

6.1 Limitations of technique or methodology can limit the value of the procedure. Erroneous results can arise from

6.1.1 sample clotting due to improper anticoagulation or improper mixing 1,3,39-41,59

6.1.2 sample contamination by

\subsubsection{1 air}

6.1.2.2 improper anticoagulant and/or improper anticoagulant concentration

6.1.2.3 saline or other fluids (specimen obtained via an indwelling catheter)
6.1.2.4 inadvertent sampling of venous blood if attempting to obtain an $\mathrm{ABG}$

6.1.3 deterioration or distortion of variables to be measured resulting from

6.1.3.1 delay in sample analysis (section 4.5)

6.1.3.2 inappropriate collection and handling. Accurate total hemoglobin concentration measurement depends on homogeneous mixture of specimen, appropriate anticoagulant concentration and specimen-size ratio, and absence of contamination of specimen by analyzer solutions or calibration gases. The concentration measured may also be dependent on the method incorporated by the specific analyzer. ${ }^{1,3}$

6.1.3.3 incomplete clearance of analyzer calibration gases and previous waste or flushing solution $(\mathrm{s})^{3}$

6.1.4 the presence of hyperlipidemia, methylene blue, and/or hydroxocobalamin, which causes problems with analyzer membranes and may affect CO-oximetry ${ }^{16,60,61}$

6.1.5 inappropriate sample size for the type of anticoagulant $\mathrm{t}^{1,4,5,7}$ and/or the sample requirements of the analyzer(s). ${ }^{38}$ Attempts should be made to keep sample sizes as small as is technically feasible, to limit blood loss, particularly in neonates. ${ }^{1}$ 6.1.6 the presence of dyshemoglobins. Some calculated values may be in error (eg, calculated $\mathrm{S}_{\mathrm{aO}_{2}}$ may overestimate oxyhemoglobin saturation in the presence of carboxyhemoglobin or methemoglobin, and with changes in diphosphoglycerate [2,3-DPG] concentration).

6.1.7 the presence of excess fetal hemoglobin, as blood gas analyzers assume hemoglobin to be of the adult type (default), and therefore the calculated blood gas oxygen saturation values are underestimated in this instance ${ }^{62}$

6.1.8 inappropriate sample site for the analyte being assessed. Arterialized capillary samples and central venous samples may be adequate to assess $\mathrm{pH}$ and $\mathrm{P}_{\mathrm{CO}_{2}}$ in hemodynamically stable patients, but may underestimate patient oxygenation..$^{9,11,29}$ 6.1.9 temperature related errors. The laboratory must have a defined procedure for temperature correction of the measured results. Errors in the measurement of the patient's temperature may cause erroneous temperature-corrected results. If temperature-adjusted results are reported, the report should be clearly labeled as such, and the measured results at $37^{\circ} \mathrm{C}$ must also be reported. ${ }^{3}$ It should be noted that no data are currently available to quantify the balance between oxygen delivery and oxygen demand at temperatures other 
than $37^{\circ} \mathrm{C}$, and that temperature correction of blood gas samples is not recommended.63

6.1.10 hemodilution or altered osmolality when measuring hematocrit using conductometry sensor technology 1,52

6.1.11 high speed transport tube systems, which may produce erroneous $\mathrm{P}_{\mathrm{O}_{2}}$ results. ${ }^{64}$ Specifically, samples with a $\mathrm{P}_{\mathrm{O}_{2}}$ above that of ambient air may be underestimated, and those with a $\mathrm{P}_{\mathrm{O}_{2}}$ below that of ambient air may be overestimated. ${ }^{65-67}$

6.2 Results of analysis can be considered valid if

6.2.1 analytic procedure conforms to recommended, established guidelines ${ }^{3,38}$ and follows manufacturer's recommendations

6.2.2 results of the $\mathrm{pH}$ analysis fall within the calibration range of the analyzer(s) and quality control product ranges..$^{16}$ If a result outside of the usual calibration range is obtained (eg, $\mathrm{P}_{\mathrm{aO}}$ measured as $250 \mathrm{~mm} \mathrm{Hg}$, but analyzer calibrated to $140 \mathrm{~mm} \mathrm{Hg}$ ), refer to the manufacturer's instructions for the particular machine in use.

6.2.3 laboratory procedures and personnel are in conformance with quality control and recognized proficiency testing programs ${ }^{3,16,37,38}$

6.3 If questionable results are obtained and are consistent with specimen contamination:

6.3.1 the labeling of the blood sample container should be rechecked for the patient's full name, medical record number, or date of birth (patient identifier), date and time of acquisition, and measured $\mathrm{F}_{\mathrm{IO}_{2}}$ (or supplemental oxygen flow) , $^{1,3}$

6.3.2 the residual specimen should be reanalyzed (preferably on a separate analyzer), assuming sufficient sample remains

6.3.3 an additional sample should be obtained if the discrepancy cannot be resolved

6.3.4 results of analysis of discarded samples should be logged with reason for discarding 16

6.4 Central venous oxygen saturation may not reliably predict (overestimate) mixed venous oxygen saturation in patients with severe sepsis in early goal-directed therapies. ${ }^{68,69}$

6.5 VBG values should be interpreted as interchangeable with ABG only in very specific clinical conditions:

6.5.1 Available evidence suggests that there is good agreement for $\mathrm{pH}$ and $\mathrm{HCO}_{3}$ values between arterial and VBG results obtained from a peripheral vein in patients with COPD, but not for $\mathrm{P}_{\mathrm{O}_{2}}$ or $\mathrm{P}_{\mathrm{CO}_{2}} \cdot{ }^{70,71}$

6.5.2 $\mathrm{VBG} \mathrm{pH}$ and $\mathrm{P}_{\mathrm{CO}_{2}}$ levels have relatively good correlation with $\mathrm{ABG}$ values, but cannot be substituted for ABG in exacerbation of COPD or in the setting of acute trauma. ${ }^{72,73}$
6.5.3 While a VBG may be used instead of ABG to determine $\mathrm{pH}, \mathrm{P}_{\mathrm{CO}_{2}}$, and $\mathrm{HCO}_{3}$ in some diseases, such as respiratory distress syndrome, neonatal sepsis, renal failure, pneumonia, diabetic ketoacidosis, and status epilepticus, it should not be used as a substitute in other diseases such as neonatal seizure, shock, congestive heart failure, and congenital heart diseases. ${ }^{74}$

6.5.4 The presence of a high central venousarterial $\mathrm{P}_{\mathrm{CO}_{2}}$ difference helps identify inadequacy of circulatory response as the one present in severe hemorrhagic shock, poor cardiac output, during cardiopulmonary resuscitation, and after cardiopulmonary bypass. ${ }^{24-28}$

\section{BGA 7.0 ASSESSMENT OF NEED}

The presence of a valid indication (BGA 3.0) in the subject to be tested supports the need for sampling and analysis. Results of BGA should either help diagnose or confirm the presence of a disease, or potentially alter patient treatment.

\section{BGA 8.0 ASSESSMENT OF QUALITY OF TEST AND VALIDITY OF RESULTS}

The consensus of the committee is that all diagnostic procedures should follow the quality model described in the Clinical and Laboratory Standards Institute document GP26-A4, "Quality Management System: A Model for Laboratory Services." 75 The document describes a laboratory path of workflow model that incorporates all the steps of the procedure. This process begins with patient assessment and the generation of a clinical indication for testing through the application of the test results to patient care. The quality system essentials defined for all healthcare services provide the framework for managing the path of workflow. A continuation of this model for respiratory care services is further described in the Clinical and Laboratory Standards Institute document HS4-A, "Application of a Quality System Model for Respiratory Services." 76 In both quality models the patient is the central focus.

8.1 General considerations include:

8.1.1 As part of any quality assurance program, indicators must be developed to monitor areas addressed in the path of workflow.

8.1.2 Each laboratory should standardize procedures and demonstrate inter-technologist reliability. Test results can be considered valid only if they are derived according to and conform to established laboratory quality control, quality assurance, and monitoring protocols.

8.1.3 Documentation of results, therapeutic intervention (or lack of), and/or clinical decisions based 
on testing should be placed in the patient's medical record.

8.1.4 The mode of ventilation, oxygen concentration, oxygen delivery device, and results of the pretest assessment should be documented. These should also be placed in the patient's medical record.

8.1.5 The report of test results should contain a statement by the licensed medical professional performing the test regarding test quality (including patient understanding of directions and effort expended) and, if appropriate, which recommendations were not met. ${ }^{54}$

8.1.6 Test results should be interpreted by a physician or qualified medical professional, taking into consideration the clinical question to be answered.

8.1.7 There must be evidence of active review of quality control, proficiency testing, and physician alert, or critical values, on a level commensurate with the number of tests performed. ${ }^{77}$

8.2 Blood gas $\mathrm{pH}$ analysis and hemoximetry are beneficial only if pre-analytical error has not occurred. ${ }^{3}$ 8.3 Considerations related to equipment quality control and control materials

8.3.1 For internal-equipment quality control using commercial controls:

8.3.1.1 Establish the mean and standard deviation for each constituent (ie, $\mathrm{pH}, \mathrm{P}_{\mathrm{CO}_{2}}$, $\mathrm{P}_{\mathrm{O}_{2}}$ ) in each level for a new lot number of commercial quality control material prior to expiration of the old lot number. The laboratory director or designee should determine the acceptable range for quality control results, based on statistically relevant or medical-needs criteria.

8.3.1.2 The frequency of each control run and number of levels is dependent on regulatory requirements and manufacturer's recommendations. ${ }^{16}$

8.3.1.3 Quality control results outside predefined acceptability limits should trigger equipment troubleshooting. Quality control must be verified to be "in control" prior to analysis of specimens. Appropriate documentation of actions taken and results of verification is required.

8.3.1.4 Duplicate specimen analysis (ie, twice on one instrument or once on two instruments) may also be performed on a regular basis, as an additional method of quality control. Duplicate analysis of the same analytes on different models of equipment is generally required by accrediting agencies, and should be cross-checked twice a year for correlation of results. ${ }^{54}$ However, oxygen saturation measurements have been shown to vary significantly, even between identical devices, in the setting of moderate to severe hypoxemia. ${ }^{78}$

8.3.1.5 Tonometry is the reference procedure to establish accuracy for blood $\mathrm{P}_{\mathrm{O}_{2}}$ and $\mathrm{P}_{\mathrm{CO}_{2}}$. If issues of true accuracy arise, tonometry should be available. 3,79

8.3.1.6 Electronic quality control monitors only the equipment performance. The use of non-electronic controls at periodic intervals should also be employed to evaluate the testing process. ${ }^{3}$

8.3.1.7 Record keeping. Summarize all quality control data for a specified lot number. Maintain and generate reports according to regulatory and institutional policy.

8.3.2 External quality control or proficiency testing $^{3}$ considerations

8.3.2.1 Proficiency testing is required by the Clinical Laboratory Improvement Amendments of $2004^{16}$ for each regulated analyte. Specimens of unknown values from an external source are to be analyzed a minimum of 3 times a year.

8.3.2.2 Proficiency-testing materials should be obtained from an approved source to meet regulatory requirements.

8.3.2.3 The proficiency testing survey report should be carefully reviewed by the medical director and laboratory supervisor. If the results are suboptimal, the medical director and supervisor should promptly review their equipment, procedures, and materials to ascertain the cause of the poor performance. ${ }^{80}$

8.3.3 With new equipment installation ${ }^{80}$ :

8.3.3.1 the Clinical Laboratory Improvement Amendments of 2004 require the evaluation of equipment accuracy and imprecision prior to analysis of patient samples. ${ }^{16}$

8.3.3.2 Tonometry is the reference method for establishing accuracy for $\mathrm{P}_{\mathrm{aO}_{2}}$ and $\mathrm{P}_{\mathrm{aCO}_{2}},{ }^{79}$ but unless the entire tonometry process is of the highest quality, it too can have errors.

8.3.3.3 When an existing instrument is replaced, duplicate analysis must be performed to compare the new instrument to the existing instrument.

8.3.4 Calibration verification ${ }^{80}$

8.3.4.1 Calibration verification is performed prior to initial use and at 6-month intervals. Calibration verification is completed by an- 
alyzing a minimum of 3 levels of control material to verify the measuring range of the analyzer. A fourth level should be considered if samples with high $\mathrm{O}_{2}$ levels are analyzed on the instrument.

8.3.4.2 Frequency of calibration verification may vary according to regulatory agencies under which the laboratory is accredited or licensed (ie, College of American Pathologists or the Joint Commission).

8.4 Testing (analytical phase) is carried out according to an established proven protocol, conforming to manufacturer recommendations. ${ }^{3,38}$ The following aspects of analysis should be monitored and corrective action taken as indicated:

8.4.1 detection of presence of air bubbles or clots in specimen, with evacuation prior to mixing and sealing of syringe ${ }^{1,3,7}$

8.4.2 assurance that an uninterrupted (ie, continuous) sample is drawn (or injected) into the analyzer, and that all of the electrodes are covered by the sample (confirmed by direct viewing of sample chamber if possible) ${ }^{38,53}$

8.4.3 assurance that 8-hour quality control and calibration procedures have been completed and that instrumentation is functioning properly prior to patient sample analysis s $^{3,16,37}$

8.4.4 assurance that specimen was properly labeled, stored, and analyzed within an acceptable period of time $\mathrm{e}^{1,3}$ (see section 4.5)

8.5 Post-testing (post-analytical phase). The results should validate or contradict the patient's clinical condition (ie, the basis for ordering the test). ${ }^{81-83}$

8.5.1 Documentation of results, therapeutic intervention (or lack of), and/or clinical decisions based upon the pH-blood gas measurements should be available in the patient's medical record and/or be otherwise readily accessible (eg, at the testing area) for at least 2 years. ${ }^{16}$

8.5.2 Reference intervals and "critical values" must be determined for each analyte prior to sample analysis. If the reference interval is determined by transference, the interval should be validated. Defining and determining reference intervals is described in the Clinical and Laboratory Standards Institute document C24-A3. ${ }^{84}$

\section{BGA 9.0 RESOURCES}

Federal regulations ${ }^{16}$ stipulate that requirements relative to personnel (levels of education and training), documentation procedures, and equipment be fulfilled. Blood gas instrumentation is classified as being either moderately or highly complex. Persons performing blood gas analysis should be conversant with applicable federal regulations (Clinical Laboratory Improvement Amendments of 2004) $^{16}$ and appropriately qualified. In addition to federal regulations, state regulatory requirements for blood gas analysis must also be met.

9.1 Recommended equipment

9.1.1 Automated or semi-automated $\mathrm{pH}$-blood gas analyzer with related calibration gases, electrodes, membranes, electrolytes, reagents, and accessories $^{3,16,38}$

9.1.2 Fixed, multiple wavelength spectrophotometer (hemoximeter or CO-oximeter) ${ }^{32}$ or other device for determining total hemoglobin and its components

9.1.3 Protective eye wear, as necessary, and outer wear, protective gloves, impenetrable needle container, face mask, and/or face-shield ${ }^{57}$

9.1.4 Quality control and proficiency testing materials

\subsection{Personnel}

The following recommendations are for tests of moderate complexity, as designated by the Clinical Laboratory Improvement Amendments of 2004. ${ }^{16}$ Persons at either of the levels described should perform $\mathrm{pH}-$ blood gas analysis under the direction and responsibility of a laboratory director and technical consultant (may be the same individual) who possess at least a baccalaureate degree and who have specific training in blood gas analysis and interpretation. ${ }^{16}$

9.2.1 Level 1. Personnel should be specifically trained in $\mathrm{pH}$-blood gas analysis, oxygen delivery devices, and related equipment, record keeping, and hazards, and sources of specimen and handler contamination(s) associated with sampling and analysis. Such persons should be, at minimum, high school graduates (or equivalent), with strong background in mathematics, and preferably with one or more years of college courses in the physical and biological sciences. ${ }^{85}$ Such persons must have documented training and demonstrated proficiency in pH-blood gas analysis, preventive maintenance, troubleshooting, instrument calibration, and awareness of the factors that influence test results, and the skills required to verify the validity of test results through the evaluation of quality-control sample values, prior to analyzing patient specimens and reporting results. ${ }^{16,84}$ Performance of pH-blood gas analysis must be supervised by a Level 2 technologist.

9.2.2 Level 2. Level 2 personnel supervise Level 1 personnel and are healthcare professionals specifically trained (with proven, documented proficiency) in all aspects of blood gas analysis and hemoximetry: 
9.2.2.1 quality control, quality assurance, and proficiency testing

9.2.2.2 operation and limitations, including instrument troubleshooting and appropriate corrective measures

9.2.2.3 Level 2 personnel should be cognizant of various means for specimen collection and the causes and impact of pre-analytical and instrument error(s).

9.2.2.4 Level 2 personnel should be trained in patient assessment, acid-base and oxygenation disorders, and diagnostic and therapeutic alternatives. A baccalaureate or higher degree in the sciences or substantial experience in pulmonary function technology is preferred, although 2 years of college in biological sciences and mathematics, plus 2 years of training and experience, or equivalent may be substituted for personnel supervising arterial $\mathrm{pH}$-blood gas analysis. ${ }^{76,84} \mathrm{~A}$ nationally recognized credential (MT, MLT, CRT, RRT, CPFT, RPFT, RN) is strongly recommended. ${ }^{16}$

9.3 Personnel who do not meet annual competency requirements, or whose competency is deemed unacceptable as documented in an occurrence report, should not be allowed to participate until they have received remedial instruction and have been re-evaluated.

\section{BGA 10.0 MONITORING}

Monitoring of personnel, sample handling, and analyzer performance to assure proper handling, analysis, and reporting should be ongoing, during the process.

\section{BGA 11.0 FREQUENCY}

Frequency of execution of quality control maneuvers depends upon the sample load of the laboratory and the requirements of agencies that specify those maneuvers.

\section{BGA 12.0 INFECTION CONTROL}

12.1 The staff, supervisors, and physician-directors associated with the blood gas laboratory should be conversant with "Guideline for Isolation Precautions in Hospitals" from the Centers for Disease Control and Prevention and the Hospital Infection Control Practices Advisory Committee. ${ }^{86,87}$ The blood gas laboratory staff should develop and implement policies and procedures for the laboratory that conform with these recommendations for standard precautions and transmission-based precautions.
12.2 The laboratory's manager and its medical director should maintain communication and cooperation with the institution's infection control service and the personnel health service, to help assure consistency and thoroughness in conforming with the institution's policies related to immunizations, post-exposure prophylaxis, and job- and community-related illnesses and exposures. ${ }^{56}$

12.3 Primary considerations include:

12.3.1 adequate hand-washing 88,89

12.3.2 provision of prescribed ventilation, with adequate air exchanges ${ }^{90,91}$

12.3.3 careful handling and thorough cleaning and processing of equipment ${ }^{58}$

12.3.4 the exercise of particular care in scheduling and interfacing with the patient in whom a diagnosis has not been established ${ }^{56,57}$

\section{BGA 13.0 AGE-SPECIFIC ISSUES}

This document applies to samples from neonatal, pediatric, adult, and geriatric populations.

\section{BGA 14.0 RECOMMENDATIONS}

The following recommendations are made following the Grading of Recommendations Assessment, Development, and Evaluation criteria. ${ }^{69}$

14.1 BGA and hemoximetry are recommended for evaluating a patient's ventilatory, acid-base, and/or oxygenation status. (1A)

14.2 BGA and hemoximetry are suggested for evaluating a patient's response to therapeutic interventions. (2B)

14.3 BGA and hemoximetry are recommended for monitoring severity and progression of documented cardiopulmonary disease processes. (1A)

14.4 Hemoximetry is recommended to determine the impact of dyshemoglobins on oxygenation. (1A)

14.5 Capillary BGA is not recommended to determine oxygenation status. (1A)

14.6 Central venous BGA and hemoximetry are suggested to determine oxygen consumption in the setting of early goal-directed therapies. (2B)

14.7 For the assessment of oxygenation, a peripheral venous $\mathrm{P}_{\mathrm{O}_{2}}$ is not recommended as a substitute for an arterial blood measurement $\left(\mathrm{P}_{\mathrm{aO}_{2}}\right)$. (1A)

14.8 It is not recommended to use venous $\mathrm{P}_{\mathrm{CO}_{2}}$ and $\mathrm{pH}$ as a substitute for arterial blood measurement of $\mathrm{P}_{\mathrm{aCO}_{2}}$ and $\mathrm{pH}$. (2B)

14.9 It is suggested that hemoximetry is used in the detection and evaluation of shunts during diagnostic cardiac catheterization. (2B) 


\section{BGA 15.0 IDENTIFYING INFORMATION AND AVAILABILITY}

\author{
15.1 Adaptation \\ Original Publication: Respir Care 2001;46(5):498- \\ 505. \\ 15.2 Guideline developers \\ American Association for Respiratory Care Clinical \\ Practice Guidelines Steering Committee \\ Michael D Davis RRT, Department of Adult \\ Health Nursing Systems, Medical College of Vir- \\ ginia, Virginia Commonwealth University, Rich- \\ mond, Virginia \\ Brian K Walsh RRT-NPS RPFT FAARC, Boston \\ Children's Hospital, Boston, Massachusetts \\ Steve E Sittig RRT-NPS FAARC, Mayo Clinic, \\ Rochester, Minnesota \\ Ruben D Restrepo MD RRT FAARC (Chair), Uni- \\ versity of Texas Health Science Center at San Anto- \\ nio, San Antonio, Texas
}

15.3 Source(s) of funding: None.

15.4 Financial disclosures/conflicts of interest: Dr. Restrepo has disclosed relationships with Teleflex Medical, Fisher \& Paykel, and Covidien. The other authors have disclosed no conflicts of interest.

\section{REFERENCES}

1. Blonshine S, Fallon KD, Lehman CM, Sittig S; Clinical and Laboratory Standards Institute (formerly NCCLS). Procedures for the collection of arterial blood specimens; approved standard, 4th edition. Wayne, PA: CLSI; 2004. CLSI no. H11-A4.

2. Browning JA KD, Durbin CG Jr. The effect of guidelines on the appropriate use of arterial blood gas analysis in the intensive care unit. Respir Care 1989;34(4):269-276.

3. D'Orazio PD, Ehrmeyer SS, Jacobs E, Toffaletti JG, Wandrup JH; Clinical and Laboratory Standards Institute (formerly NCCLS). Blood gas and $\mathrm{pH}$ analysis and related measurements; approved guideline, 2nd edition. Wayne, PA: CLSI; 2009. CLSI no. C46-A2.

4. Criner GJ BR, D’Alonzo G. Critical care study guide: text and review. New York: Springer; 2010.

5. Lynch F. Arterial blood gas analysis: implications for nursing. Paediatr Nurs 2009;21(1):41-44.

6. PH. B. Arterial blood gas and $\mathrm{pH}$ analysis. Clinical approach and interpretation. Anesthesiol Clin N Am 2001;19(4):885-906.

7. Shapiro BA, Kozelowski-Templin R. Clinical application of blood gases. St Louis: Mosby-Year Book; 1994.

8. Ak A, Ogun CO, Bayir A, Kayis SA, Koylu R. Prediction of arterial blood gas values from venous blood gas values in patients with acute exacerbation of chronic obstructive pulmonary disease. Tohoku J Exp Med 2006;210(4):285-290.

9. Dar K, Williams T, Aitken R, Woods KL, Fletcher S. Arterial versus capillary sampling for analysing blood gas pressures. BMJ 1995; 310(6971):24-25.

10. Herrington WG, Nye HJ, Hammersley MS, Watkinson PJ. Are arterial and venous samples clinically equivalent for the estimation of $\mathrm{pH}$, serum bicarbonate and potassium concentration in critically ill patients? Diabetes Med 2012;29(1):32-35.
11. Pitkin AD, Roberts CM, Wedzicha JA. Arterialised earlobe blood gas analysis: an underused technique. Thorax 1994;49(4):364-366.

12. Walkey AJ, Farber HW, O'Donnell C, Cabral H, Eagan JS, Philippides GJ. The accuracy of the central venous blood gas for acid-base monitoring. J Intensive Care Med 2010;25(2):104-110.

13. Blasco V, Leone M, Textoris J, Visintini P, Albanèse J, Martin C. [Venous oximetry: physiology and therapeutic implications]. Ann Fr Anesth Réanim 2008;27(1):74-82. Article in French.

14. Christensen M. Mixed venous oxygen saturation monitoring revisited: thoughts for critical care nursing practice. Aust Crit Care 2012; 25(2):78-90.

15. Blonshine SF, Mottram C, Ruppel G, Wanger J; American Association for Respiratory Care. Clinical Practice Guideline. Blood gas analysis and hemoximetry. Respir Care 2001;46(5):498-505.

16. US Department of Health and Human Services. Clinical laboratory improvement amendments of 1988. PL 100-578.42 USC $§ 201$ (1988).

17. Society of Critical Care Medicine Task Force on Guidelines. Recommendations for services and personnel for delivery of care in a critical care setting. Crit Care Med 1988;16(8):809-811.

18. Di Serio F, Petronelli MA, Sammartino E. Laboratory testing during critical care transport: point-of-care testing in air ambulances. Clin Chem Lab Med 2010;48(7):955-961.

19. Hinkelbein JFF, Denz C, Krieter H. . Accuracy and precision of three different methods to determine $\mathrm{P}_{\mathrm{CO}_{2}}\left(\mathrm{P}_{\mathrm{aCO}_{2}}\right.$ vs $\mathrm{P}_{\mathrm{ETCO}_{2}}$ vs $\left.\mathrm{P}_{\mathrm{tcCO}_{2}}\right)$ during interhospital ground transport of critically ill and ventilated adults. J Trauma 2008;65(1):10-18.

20. Bach PB, Brown C, Gelfand SE, McCrory DC. Management of acute exacerbations of chronic obstructive pulmonary disease: a summary and appraisal of published evidence. Ann Intern Med 2001;134(7): 600-620.

21. McKinley BA, Moore FA, Sailors RM, Cocanour CS, Marquez A, Wright RK, et al. Computerized decision support for mechanical ventilation of trauma induced ARDS: results of a randomized clinical trial. J Trauma 2001;50(3):415-424; discussion 425.

22. Chuang ML LI, Vintch JR, Ho BS, Chao SW, Ker JJ. Significant exercise-induced hypoxaemia with equivocal desaturation in patients with chronic obstructive pulmonary disease. Intern Med J 2006; 36(5):294-301.

23. Marx G, Reinhart K. Venous oximetry. Curr Opin Crit Care 2006; 12(3):263-268.

24. Steedman DJ, Robertson CE. Acid base changes in arterial and central venous blood during cardiopulmonary resuscitation. Arch Emerg Med 1992;9(2):169-176.

25. Weil MH, Tang W, Noc M. Acid-base balance during cardiopulmonary resuscitation. Crit Care Med 1993;21(9 Suppl):S323-S324.

26. Idris AH, Staples ED, O’Brien DJ, Melker RJ, Rush WJ, Del Duca $\mathrm{KD}$, et al. Effect of ventilation on acid-base balance and oxygenation in low blood-flow states. Crit Care Med 1994;22(11):1827-1834.

27. Utoh J, Moriyama S, Goto H, Hirata T, Kunitomo R, Hara M, et al. [Arterial-venous carbon dioxide tension difference after hypothermic cardiopulmonary bypass]. Nihon Kyobu Geka Gakkai Zasshi 1997; 45(5):679-681. Article in Japanese.

28. Futier E, Robin E, Jabaudon M, Guerin R, Petit A, Bazin JE, et al. Central venous $\mathrm{O}_{2}$ saturation and venous-to-arterial $\mathrm{CO}_{2}$ difference as complementary tools for goal-directed therapy during high-risk surgery. Crit Care 2010;14(5):R193.

29. MacRae DJ, Palavradji D. Comparison between arterial, capillary, and venous acid-base measurements in the newborn infant. J Obstet Gynaecol Br Commonw 1966;73(5):761-765.

30. Gokel Y, Paydas S, Koseoglu Z, Alparslan N, Seydaoglu G. Comparison of blood gas and acid-base measurements in arterial and venous blood samples in patients with uremic acidosis and diabetic ketoacidosis in the emergency room. Am J Nephrol 2000;20(4):319323. 


\section{AarC Clinical Practice Guideline: Blood Gas Analysis and Hemoximetry: 2013}

31. Ma OJ, Rush MD, Godfrey MM, Gaddis G. Arterial blood gas results rarely influence emergency physician management of patients with suspected diabetic ketoacidosis. Acad Emerg Med 2003;10(8): 836-841.

32. ECRI Institute. Assessing respiratory status with blood gas/pH analyzers and in vitro multiwavelength oximeters. Health Devices 1989; 18(7-8):239-284.

33. Ehrmeyer SS, Laessig RH. Alternative statistical approach to evaluating interlaboratory performance. Clin Chem 1985;31(1):106-108.

34. Elser RC. Quality control of blood gas analysis: a review. Respir Care 1986;31(9):807-816.

35. Hansen JE, Jensen RL, Casaburi R, Crapo RO. Comparison of blood gas analyzer biases in measuring tonometered blood and a fluorocarbon-containing, proficiency-testing material. Am Rev Respir Dis 1989;140(2):403-409.

36. Hansen JE CR, Crapo RO, Jensen RL. Assessing precision and accuracy in blood gas proficiency testing. Am Rev Respir Dis 1990; 141(5 Pt 1):1190-1193

37. Moran RF. Assessment of quality control of blood gas/pH analyzer performance. Respir Care 1981;26(6):538-546.

38. Toffaletti JG, McDonnell EH, Ramanathan LV, Tolnai J, Templin R, Pompa L. Validation of a quality assessment system for blood gas and electrolyte testing. Clin Chim Acta 2007;382(1-2):65-70.

39. Higgins $\mathrm{C}$. The use of heparin in preparing samples for blood-gas analysis. MLO Med Lab Obs 2007;39(10):16-18, 20; quiz 22-23.

40. Arkin CF, Ernst DJ, Marlar A, Parish GT, Szamosi DI, Wiseman JD; Clinical and Laboratory Standards Institute (formerly NCCLS). Tubes and additives for venous blood specimen collection; approved standard, 5th edition. Wayne, PA: CLSI; 2003. CLSI no. H1-A5.

41. Cissik JH SJ, Patton OL, Louden JA. The effects of sodium heparin on arterial blood-gas analysis. CVP Jan/Feb 1977.

42. Deane JC, Dagleish MP, Benamou AE, Wolf BT, Marlin D. Effects of syringe material and temperature and duration of storage on the stability of equine arterial blood gas variables. Vet Anaesth Analg 2004;31(4):250-257.

43. Fox MJ, Brody JS, Weintraub LR. Leukocyte larceny: a cause of spurious hypoxemia. Am J Med 1979;67(5):742-746.

44. Matchuny JK. Unexplained hypoxemia in a leukemia patient. Respir Care 1988;33(10):971-973.

45. Knowles TP, Mullin RA, Hunter JA, Douce FH. Effects of syringe material, sample storage time, and temperature on blood gases and oxygen saturation in arterialized human blood samples. Respir Care 2006;51(7):732-736.

46. Mahoney JJ, Harvey JA, Wong RJ, Van Kessel AL. Changes in oxygen measurements when whole blood is stored in iced plastic or glass syringes. Clin Chem 1991;37(7):1244-1248.

47. Muller-Plathe O, Heyduck S. Stability of blood gases, electrolytes and haemoglobin in heparinized whole blood samples: influence of the type of syringe. Eur J Clin Chem Clin Biochem 1992;30(6):349355.

48. Smeenk FW, Janssen JD, Arends BJ, Harff GA, van den Bosch JA, Schonberger JP, et al. Effects of four different methods of sampling arterial blood and storage time on gas tensions and shunt calculation in the 100\% oxygen test. Eur Respir J 1997;10(4):910-913.

49. Woolley A, Hickling K. Errors in measuring blood gases in the intensive care unit: effect of delay in estimation. J Crit Care 2003; 18(1):31-37.

50. Wu EY, Barazanji KW, Johnson RL Jr. Source of error on A-aDO2 calculated from blood stored in plastic and glass syringes. J Appl Physiol 1997;82(1):196-202.

51. McCrory DC, Brown C, Gelfand SE, Bach PB. Management of acute exacerbations of COPD: a summary and appraisal of published evidence. Chest 2001;119(4):1190-1209.
52. Kastrup M, Carl M, Spies C, Sander M, Markewitz A, Schirmer U. Clinical impact of the publication of S3 guidelines for intensive care in cardiac surgery patients in Germany: results from a postal survey. Acta Anaesthesiol Scand 2013;57(2):206-213.

53. The Joint Commission. National patient safety goals. Oakbrook Terrace, IL: The Joint Commission; 2013. http://www.jointcommission. org/standards_information/npsgs.aspx. Accessed July 23, 2013.

54. College of American Pathologists. CAP personnel requirements by testing complexity. http://www.cap.org/apps/docs/laboratory_ accreditation/build/pdf/personnel_requirements_by_testing_com plexity.pdf. Accessed July 23, 2013.

55. Malley W. Clinical blood gases. St Louis: Elsevier; 2005:79.

56. Centers for Disease Control and Prevention, Hospital Infection Control Practices Advisory Committee. Guideline for infection control in health care personnel. Am J Infect Control 1998;26:269-354. Also in: Infect Control Hosp Epidemiol 1998;19(6):407-463.

57. Occupational Safety and Health Administration. Occupational safety and health standards. Toxic and hazardous substances: bloodborne pathogens. Washington, DC: OSHA. Standards 29 CFR, Part 1910.1030 .

58. Hooton TM. Protecting ourselves and our patients from nosocomial infections. Respir Care 1989;34(2):111-115.

59. Seyfert UT, Biehl V, Schenk J. In vitro hemocompatibility testing of biomaterials according to the ISO 10993-4. Biomol Eng 2002;19(26):91-96

60. Reynolds H, Dulhunty J, Tower M, Taraporewalla K, Rickard C. A snapshot of guideline compliance reveals room for improvement: A survey of peripheral arterial catheter practices in Australian operating theatres. J Adv Nurs 2013;69(7):1584-1594.

61. Baker RA, Newland RF, Fenton C, McDonald M, Willcox TW, Merry AF. Developing a benchmarking process in perfusion: a report of the Perfusion Downunder Collaboration. J Extra Corpor Technol 2012;44(1):26-33.

62. Pomerance J. Interpreting umbilical blood gases: for clinicians caring for the fetus or newborn, 2nd edition. Glendora, CA: Beverly Newborn Medical Group; 2012:24.

63. Shapiro B. Temperature correction of blood gas values. Respir Clin N Am 1995;1(1):69-76.

64. Restrepo RD, Hirst KR, Wittnebel L, Wettstein R; American Association for Respiratory Care. Clinical Practice Guideline. Transcutaneous monitoring of carbon dioxide and oxygen: 2012. Respir Care 2012;57(11):1955-1962.

65. Astles JR, Lubarsky D, Loun B, Sedor FA, Toffaletti JG. Pneumatic transport exacerbates interference of room air contamination in blood gas samples. Arch Pathol Lab Med 1996;120(7):642-647.

66. Lu JY, Kao JT, Chien TI, Lee TF, Tsai KS. Effects of air bubbles and tube transportation on blood oxygen tension in arterial blood gas analysis. J Formos Med Assoc 2003;102(4):246-249.

67. McKane MH, Southorn PA, Santrach PJ, Burritt MF, Plevak DJ. Sending blood gas specimens through pressurized transport tube systems exaggerates the error in oxygen tension measurements created by the presence of air bubbles. Anesth Analg 1995;81(1):179-182.

68. Napoli AM, Machan JT, Forcada A, Corl K, Gardiner F. Tissue oxygenation does not predict central venous oxygenation in emergency department patients with severe sepsis and septic shock. Acad Emerg Med 2010;17(4):349-352.

69. van Beest PA, van Ingen J, Boerma EC, Holman ND, Groen H, Koopmans M, et al. No agreement of mixed venous and central venous saturation in sepsis, independent of sepsis origin. Crit Care 2010;14(6):R219.

70. Wenzel V, Krismer AC, Mayr VD, Voelckel WG, Strohmenger HU, Lindner KH. [Drug therapy in cardiopulmonary resuscitation]. Wien Klin Wochenschr 2001;113(23-24):915-926. Article in German. 


\section{AarC Clinical Practice Guideline: Blood Gas Analysis and Hemoximetry: 2013}

71. Lim BL, Kelly AM. A meta-analysis on the utility of peripheral venous blood gas analyses in exacerbations of chronic obstructive pulmonary disease in the emergency department. Eur J Emerg Med 2010;17(5):246-248.

72. Neudecker J, Sauerland S, Neugebauer E, Bergamaschi R, Bonjer HJ, Cuschieri A, et al. The European Association for Endoscopic Surgery clinical practice guideline on the pneumoperitoneum for laparoscopic surgery. Surg Endosc 2002;16(7):1121-1143.

73. Razi E, Moosavi GA. Comparison of arterial and venous blood gases analysis in patients with exacerbation of chronic obstructive pulmonary disease. Saudi Med J 2007;28(6):862-865.

74. Bilan N, Behbahan AG, Khosroshahi AJ. Validity of venous blood gas analysis for diagnosis of acid-base imbalance in children admitted to pediatric intensive care unit. World J Pediatr 2008;4(2):114117.

75. CLSI. Quality management system: a model for laboratory services; approved guideline $-4^{\text {th }}$ edition. CLSI document GP26-A4. Wayne, PA: Clinical and Laboratory Standards Institute; 2011.

76. National Committee for Clinical Laboratory Standards. NCCLS HS4-A. Application of a quality system model for respiratory services; approved guideline. http://isoforlab.com/phocadownload/csli/ HS4-A.pdf. Accessed July 23, 2013.

77. Roberts CM, Ryland I, Lowe D, Kelly Y, Bucknall CE, Pearson MG. Audit of acute admissions of COPD: standards of care and management in the hospital setting. Eur Respir J 2001;17(3):343-349.

78. Merlani P, Garnerin P, Diby M, Ferring M, Ricou B. Quality improvement report: Linking guideline to regular feedback to increase appropriate requests for clinical tests: blood gas analysis in intensive care. BMJ 2001;323(7313):620-624.

79. Burnett RW, Covington AK, Maas AH, Muller-Plathe O, Weisberg HF, Wimberley PD, et al; International Federation of Clinical Chemistry (IFCC), Scientific Division Committee on $\mathrm{pH}$. Blood gases and electrolytes IFCC method (1988) for tonometry of blood: reference materials for $\mathrm{P}_{\mathrm{CO}_{2}}$ and $\mathrm{P}_{\mathrm{O}_{2}}$. J Clin Chem Clin Biochem 1989;27(6): 403-408.

80. Berte LM, Boone DJ, Cooper G, James PL, Kallner A, Nobel MA, Tholen DW; Clinical and Laboratory Standards Institute (formerly NCCLS). Application of a quality management system model for laboratory services; approved guideline, 3rd edition. Wayne, PA: CLSI; 2004. CLSI no. GP26-A3.

81. Marino PL Sk. The ICU book. Philadelphia: Lippincott Williams \& Wilkins; 2007.

82. Sasse SA, Chen PA, Mahutte CK. Variability of arterial blood gas values over time in stable medical ICU patients. Chest 1994;106(1): 187-193.

83. Thorson SH MJ, Pierson DJ, Hudson LD. Variability of arterial blood gas values in stable patients in the ICU. Chest 1983;84(1):1418.

84. Clinical and Laboratory Standards Institute (formerly NCCLS). Statistical quality control for quantitative measurement procedures: principles and definitions; approved guideline, 3rd edition. Wayne, PA: CLSI; 2008. CLSI no. C24-A3.

85. Gardner RM CJ, Epler G, Hankinson JL, Permutt S, Plammer AL; ATS Position Paper. Pulmonary function laboratory personnel qualifications. ATS News November 1982.

86. Garner JS. Guideline for isolation precautions in hospitals. The Hospital Infection Control Practices Advisory Committee. Infect Control Hosp Epidemiol 1996;17(1):53-80.

87. Gasink LB, Brennan PJ. Isolation precautions for antibiotic-resistant bacteria in healthcare settings. Curr Opin Infect Dis 2009;22(4):339344.

88. Allegranzi B, Pittet D. Role of hand hygiene in healthcare-associated infection prevention. J Hosp Infect 2009;73(4):305-315.

89. World Health Organization. who guidelines on hand hygiene in health care. Geneva: WHO; 2009.

90. Jensen PA, Lambert LA, Iademarco MF, Ridzon R; Centers for Disease Control and Prevention. Guidelines for preventing the transmission of Mycobacterium tuberculosis in health-care facilities. MMWR Recomm Rep 2005;54(RR-17):1-141.

91. Griffith DE AT, Brown-Elliott BA, Catanzaro A, Daley C, Gordin F, Holland SM, Horsburgh R, et al; ATS Mycobacterial Diseases Subcommittee; American Thoracic Society; Infectious Disease Society of America. Diagnosis, treatment, and prevention of nontuberculous mycobacterial diseases. Am J Respir Crit Care Med 2007;175(4): 367-416. Erratum in: Am J Respir Crit Care Med 2007;175(7):744745 . 